\title{
PENINGKATAN KEMAMPUAN MEMECAHKAN MASALAH MELALUI MEDIA KOMPUTER DALAM PEMBELAJARAN MATEMATIKA PADA SISWA SMKN 1 NGAWEN
}

\author{
Urip Haryanto \\ SMK Negeri 1 Ngawen Gunungkidul \\ E-mail: haryanto.urip@yahoo.com
}

\begin{abstract}
This study aims at improving the students' problem solving ability of Mathematics through computerbased learning, particularly in the space figures competency at SMK Negeri 1 Ngawen Gunungkidul. This study is categorized as classroom action research. The subjects of the study were the grade XI OC students of SMK Negeri 1 Ngawen Gunung Kidul. The study consisted of repetitious cycles. Every cycle consisted of problem identification, planning, action, observation, and reflection. The results of the study showed that: (1) the application of computer-based learning could improve the students' problem solving ability of Mathematics and affected positively on the students' achievement. The improvement was resulted from the conducive learning atmosphere (2) the students were highly interested in computer-based learning. They were more enthusiastic because they were able to confirm the answers directly; (3) to deal with the texts' low legibility due to the mismatch between the background and the font size, the narration orally explained by the researcher was employed (4) the application of quizzes could motivate the students. They get involved actively in answering questions. The learning activities were more varied.
\end{abstract}

Key word: Computer Media, Mathematic Learning, Problem Solving Ability

\begin{abstract}
ABSTRAK
Penelitian ini bertujuan untuk meningkatkan kemampuan memecahkan masalah melalui media komputer dalam pembelajaran matematika khususnya bangun ruang pada siswa Sekolah Menengah Kejuruan (SMK) Negeri 1 Ngawen Kabupaten Gunung Kidul. Metode penelitian mengguakan penelitian tindakan kelas dengan subjek penelitian adalah 32 siswa kelas XIOC, SMK Negeri 1 Ngawen Gunung Kidul. Hasil penelitian menunjukan bahwa: (1) peningkatan kemampuan siswa dapat meningkatkan prestasi belajar matematika. Peningkatan itu disebabkan oleh situasi pembelajaran yang kondusif. Pelaksanaan pembelajaran melalui media komputer pada pelaksanaan tindakan menarik perhatian siswa; (2) siswa senang belajar dengan media ini karena dalam pengerjaan soal siswa dapat langsung mengkonfirmasikan jawabannya; (3) cara mengatasi tingkat keterbacaan teks yang rendah akibat ketidaksesuaian background dan ukuran huruf yaitu dengan penerapan narasi, dijelaskan secara lisan oleh peneliti; dan (4) penerapan kuis mampu membangkitkan minat dan motivasi belajar. Kelompok belajar aktif mengikuti kegiatan dalam menjawab soal. Situasi pembelajaran menjadi lebih bervariasi dan tidak monoton.
\end{abstract}

Kata Kunci: Kemampuan Memecahkan Masalah, Media Komputer, Pembelajaran Matematika

\section{PENDAHULUAN}

Salah satu strategi untuk meningkatkan kualitas pendidikan adalah dengan memberikan kesempatan kepada para guru untuk menyelesaikan masalah-masalah pembelajaran dan non-pembelajaran secara profesional dan kolaboratif melaui penelitian tindakan kelas. Upaya meningkatkan kompetensi guru untuk menyelesaikan masalah-masalah pembelajaran akan memberi dampak positif ganda. Pertama, kemampuan dalam menyelesaikan masalah pembelajaran akan semakin meningkat. Kedua, penyelesaian masalah pembelajaran melalui sebuah investigasi terkendali akan dapat me- 
ningkatkan kualitas isi, masukan, proses, sarana prasarana, dan hasil belajar. Peningkatan kedua kemampuan tersebut akan bermuara pada peningkatan kualitas lulusan.

Perkembangan ilmu pengetahuan dan teknologi (IPTEK) dapat memberikan dapat positif pada peningkatan kualitas pembelajaran. Perkembangan IPTEKS mengharuskan penyesuaian dan peningkatan proses pembelajaran secara terus menerus. Disamping itu perlu adanya pemutakhiran pilihan atau konsepkonsep pembelajaran yang mendidik dan diperlukan untuk meningkatkan kualitas lulusan. Muhammad Faiq (2009) menyatakan bahwa terdapat berbagai cara pencapaian peningkatan mutu pendidikan, diantaranya ialah melalui kualitas pendidikan dan tenaga kependidikan lainnya, penelitian dan pendidikan, atau dengan memberikan kesempatan untuk menyelesaikan masalah-masalah pembelajaran dan non-pembelajaran secara profesional melalui penelitian pendidikan secara terkendali. Dimana hal tersebut dapat dilakukan menggunakan teknologi informasi.

Teknologi informasi merupakan salah satu bagian teknologi yang berkembang dengan pesat dan aplikasinya sangat luas dewasa ini. Aplikasi teknologi informasi yang nyata misalnya dengan hadirnya multimedia dan web, dalam bidang pendidikan yang melahirkan terobosan baru dalam meningkatkan efisien dan efektivitas proses pembelajaran. Perkembangan teknologi informasi akhir-akhir ini memungkinkan guru untuk melakukan aktivitasnya dengan berbagai kemudahan. Komputer juga dapat dimanfaatkan untuk pembelajaran. Hujair (2009) menyatakan bahwa pembelajaran di sekolah mulai menyesuaikan dengan adanya perkembangan teknologi informasi. Hal tersebut menunjukkan bahwa penggunaan komputer sebagai salah satu perangkat teknologi informasi dalam pembelajaran merupakan suatu kebutuhan. Namun demikian penggunaan komputer pada pembelajaran Matematika di SMK N 1 Ngawen belum dilakukan secara optimal.
Penggunaan komputer sebagai perangkat teknologi informasi dan komunikasi (TIK) dapat mengoptimalkan pencapaian tujuan pembelajaran. Namun demikian, pemanfaatan TIK dalam dunia pendidikan memiliki beberapa kendala, di antaranya yaitu: (1) Kurangnya pengadaan infrastruktur TIK; (2) Ketidaksiapaan sumber daya manusia untuk memanfaatkan TIK dalam proses pembelajaran; (3) Beberapa hambatan penggunaan TIK dalam proses belajar mengajar seperti: (a) kurangnya kepercayaan diri guru menggunakan TIK dalam melaksanakan proses belajar mengajar; (b) kurangnya kompetensi guru dalam mengintegrasikan TIK ke dalam pedagogis praktik; dan (c) sikap guru dan resistensi terhadap perubahan; (4) Penggunaan perangkat multimedia bekas, sehingga penggunaannya tidak mampu bersaing dengan laju perkembangan TIK yang begitu pesat; dan (5) Mahalnya biaya pengadaan dan penggunaan fasilitas TIK (Purnama, 2013). Dari berbagai hambatan tersebut, hambatan utamanya adalah rendahnya presentase keterbacaan komputer (computer literacy) yang ada di kalangan tenaga pendidik dan terbatasnya sarana pendidikan yang tersedia di sekolah secara umum. Salah satu upaya yang dapat dilakukan untuk mengatasi berbagai hambatan tersebut adalah menyediakan materi yang berkualitas, bermakna, dan dukungan kultural bagi pembelajar dan pengajar berupa materi pembelajaran interaktif yang berbantuan komputer.

Langkah proaktif harus dilakukan secara mandiri oleh para guru untuk meningkatkan diri agar dapat memanfaatkan bantuan komputer dalam pembelajaran. Prinsip-prinsip pembelajaran yang dikembangkan oleh para pakar pendidikan ternyata sangat terarah dengan kekuatan dan kelebihan sebuah komputer mikro. Dalam kemampuan komputer mikro, sebagian besar teknik yang diaplikasikan dalam bidang pendidikan dapat diwadahi. Matematika sebagai ilmu yang sarat dengan konsep abstrak dirasakan oleh sebagian besar siswa sebagai ilmu yang sulit untuk dikuasai, tidak tampak jelas penggunaannya dalam kehidupan sehari-hari 
walaupun sangat banyak diterapkan dalam kehidupan. Dengan demikian menyebabkan siswa merasa kesulitan dan cenderung bosan mengikuti mata pelajaran matematika. Hal tersebut merupakan salah satu penyebab siswa kesulitan belajar matematika dari faktor psikologis (Suhas dan Suhartono, 2012). Akibatnya motivasi siswa untuk menguasai metematika secara umum sangat rendah. Apabila konsep dalam matematika dibangun dan dikembangkan secara terpadu sehingga yang terkesan bagi anak adalah matematika sebagai ilmu yang rumit. Untuk mengubah anggapan tersebut, maka diperlukan inovasi dan kreativitas guru matematika dalam merancang dan melaksanakan pembelajaran matematika.

Berdasarkan pengalaman di lapangan kelemahan siswa dalam menguasai matematika secara umum bersumber pada lemahnya penguasaan pengetahuan prasyarat, anggapan matematika hanya perlu untuk menghitung dan matematika adalah abstrak sehingga relatif sulit untuk dikuasai. Fasilitas laboratorium komputer di SMK Negeri 1 Ngawen tersedia cukup, maka untuk mengatasi hal ini peneliti tertarik untuk membuat paket pembelajaran Matematika menggunakan media komputer. Mengingat banyaknya pokok bahasan yang terdapat dalam matematika SMK, paket pembelajaran melalui media komputer yang dikembangkan dibatasi pada pokok bahasan dimensi tiga bangun ruang. Materi tersebut dipilih karena memerlukan bantuan aplikasi komputer dalam memberikan gambaran yang lebih nyata pada siswa. Paket pembelajaran ini diuji coba dan dikaji sejauh mana program tersebut menarik, efektif, efisien dan menyenangkan dipakai untuk mengatasi masalah.

Keberhasilan dalam menyelesaikan suatu masalah yang dihadapi saat menjalankan tugas akan memberi dampak positif. Peningkatan kemampuan dalam menyelesaikan masalah pendidikan dan pembelajaran yang nyata, melalui peningkatan kualitas masukan, proses dan hasil belajar. Peningkatan keprofesional pendidik melalui penerapan konsep pembelajaran berbasis penelitian tindakan kelas (PTK)/ Class- room Action Research perlu dilakukan. Upaya penelitian tindakan kelas diharapkan dapat menciptakan sebuah budaya belajar di kalangan guru-siswa di sekolah. Penelitian tindakan kelas menawarkan peluang sebagai strategi pengembangan kinerja, sebab pendekatan pada penelitian ini menempatkan pendidik dan tenaga kependidikan sebagai peneliti dan juga sebagai agen pembaharuan dengan pola kerjanya yang bersifat kolaboratif (Suwarsih Madya, 2006). Melalui PTK masalah-masalah pendidikan dan pembelajaran dapat dikaji, ditingkatkan dan dituntaskan, sehingga proses pendidikan dan pembelajaran yang inovatif dan hasil belajar yang lebih baik dapat diwujudkan secara sistematis. Hal tersebut sejalan dengan pendapat Wagiran (2015), bahwa dalam PTK dilakukan diagnosis permasalahan untuk mengidentifikasi secara komprehensif berbagai permasalahan aktual yang terjadi dalam pembelajaran atau masalah-masalah yang terkait seperti iklim kelas, sumber belajar, media belajar, pengelolaan kelas, kondisi perkembangan peserta didik. Dalam hal ini perlu diungkap/ dituliskan sebanyak mungkin berbagai permasalahan yang memerlukan perhatian atau tindakan segera melalui penelitian tindakan kelas. Dengan demikian dapat dinyatakan bahwa melalui PTK masalah-masalah pembelajaran dapat dikaji dan dituntaskan, sehingga proses pembelajaran yang inovatif dan ketercapaian tujuan pembelajaran dapat diaktualisasikan secara sistematis.

Permasalahan yang dihadapi guru di kelas terkait pembelajaran matematika adalah, bagaimana meningkatkan kemampuan pemecahan masalah melalui media komputer dalam pembelajaran matematika pada siswa SMK Negeri 1 Ngawen? Peningkatan kemampuan siswa dalam memecahkan masalah melalui pelajaran matematika tersebut akan meningkatkan prestasi belajar. Dengan penelitian tindakan kelas ini diharapkan dapat: (1) meningkatkan pembelajaran matematika melalui media komputer yang menarik, efisien, efektif dan menyenangkan; (2) meningkatkan semangat belajar siswa, sehingga siswa tertarik dan 
senang belajar matematika; (3) meningkatkan motivasi pada siswa untuk lebih senang belajar matematika, dan (4) meningkatkan pembelajaran melalui media komputer dikembangkan dalam pencapaian prestasi, untuk pokok bahasan bangn ruang dimensi tiga.

Hasil penelitian ini diharapkan dapat memberikan beberapa manfaat bagi siswa,guru, dan sekolah. Adapun manfaat tersebut adalah: (1) manfaat praktis, dan (2) manfaat teoritis. Manfaat praktis yang dimaksud adalah membantu guru memperbaiki pembelajaran, berkembang secara profesional, meningkatkan rasa percaya diri guru, meningkatkan guru secara aktif mengembangkan pengetahuan dan ketrampilan. Manfaat secara teoritis untuk meningkatkan proses atau hasil belajar siswa, disamping guru melaksanakan penelitian tindakan kelas dapat menjadi modal bagi para siswa dapat bersikap kritis terhadap hasil belajar, membantu sekolah untuk berkembang karena adanya peningkatan kemajuan pada diri guru dan pendidikan sekolah.

Fungsi media pembelajaran tidak hanya sebatas alat bantu guru dalam mengajar, tetapi juga sebagai sarana untuk mengkomunikasikan pesan kepada siswa. Media dapat menyediakan peranan yang banyak. Azhar (2007) menyatakan bahwa beberapa manfaat penggunaan media dalam proses belajar mengajar diantaranya: (1) dapat memperjelas penyajian informasi sehingga dapat memperlancar dan meningkatkan proses dan hasil belajar; (2) dapat meningkatkan dan mengarahkan perhatian anak sehingga dapat menimbulkan motivasi belajar, interaksi yang lebih langsung antara siswa dan lingkungannya, dan kemungkinan siswa untuk belajar secara mandiri sesuai dengan kemampuan dan minatnya; (3) dapat mengatasi keterbatasan indera, ruang dan waktu; dan (4) dapat memberikan kesamaan pengalaman kepada siswa tentang peristiwaperistiwa di lingkungannya, serta memungkinkan terjadinya interaksi langsung dengan guru, masyarakat, dan lingkungannya. Melihat begitu banyak peranan media pembelajaran, maka guru perlu menyajikan materi pembelajaran dengan media pembelajaran.

Pembelajaran dapat bergantung pada penyajian guru, yaitu melalui media pembelajaran. Guru Matematika di SMKN 1 Ngawen masih jarang menggunakan media pembelajaran khususnya dengan bantuan komputer di kelas. Media pembelajaran matematika perlu memperhatikan ciri yang dimiliki matematika agar sesuai dengan tujuan pembelajaran matematika. Beberapa ciri yang dimiliki oleh matematika adalah terstruktur, logis, sistematis, cermat, kritis, dan konsisten. Hal ini sejalan dengan pendapat Ansyar (2003:4) yang menyatakan sebagai berikut:

"Dalam matematika distrukturkan pola piker yang logis, sistematis, cermat, kritis, dan konsisten, disamping tuntutan atas dan inovatif. Pola piker ini dianut dengan ketat dan digunakan dengan konsisten dalam kerja matematika, baik dalam pembahasan, maupun dalam pengembangan termasuk dalam penerapan".

Mengingat ciri matematika seperti yang telah disebutkan di atas, maka hambatan utama dalam pembelajaran matematika adalah menyampaikan konsep-konsep matematika tersebut kepada siswa secara tepat agar dapat menetap dalam ingatan siswa dalam waktu yang relatif lama. Untuk keperluan ini, cara yang biasa ditempuh adalah dengan membuat alat peraga atau alat bantu mengajar. Rusefendi (1992) memaparkan alat peraga berfungsi untuk: “(1) Meningkatkan minat dalam belajar matematika (2) Lebih mudah memahami dan mengerti (3) Membantu daya titik ruang (4) Menyadarkan siswa akan adanya hubungan antara pengajaran dengan benda-benda disekitarnya (5) Konsep-konsep abstrak yang disajikan dalam bentuk konkrit dapat dijadikan obyek penelitian dan ide-ide baru dan relasirelasi baru."

Bantuan komputer dalam hal ini sangat diperlukan agar alat peraga tersebut dapat dibuat lebih menarik dalam bentuk simulasi sehingga dapat menyajikan hubungan yang bermakna atau peralihan dari yang nyata menuju yang lebih maya. Mengingat kelebihan yang dimiliki 
oleh komputer pada hampir semua aspek dari matematika maka pembelajaran matematika melalui media komputer dapat dijadikan sebagai alternatif utama untuk menyajikan pembelajaran matematika yang efektif dan efisien.

\section{METODE}

Metode yang dipakai dalam penelitian ini adalah penelitian tindakan kelas (Classroom Action Research). Jenis penelitian ini mampu menawarkan cara dan prosedur baru untuk memperbaiki dan meningkatkan profesionalisme guru dalam proses belajar mengajar. Guru dapat melakukan penelitian terhadap siswanya sendiri, dilihat dari aspek interaksi dari proses pembelajaran. Dengan melakukan penelitian tindakan guru dapat memperbaiki pembelajaran menjadi lebih efektif. Penelitian ini dilaksanakan dengan rancangan model siklus dari Kemmis dan Taggart (1990). Model siklus PTK dari Kemmis dan Taggart dapat dilihat pada Gambar 1.

Model yang dikemukakan oleh Kemmis dan Mc Taggart pada hakekatnya berupa perangkat atau untaian dengan satu perangkat yang terdiri dari empat komponen, yaitu perencanaan, tindakan, pengamatan, dan refleksi. Keempat komponen yang berupa untaian tersebut dipandang sebagai satu siklus pada kesempatan ini ialah satu putaran kegiatan yang terdiri dari perencanaan, tindakan, observasi, dan refleksi. Pada Gambar 1 tersebut tampak bahwa didalamnya terdiri dari dua perangkat komponen yang dapat dikatakan sebagai dua siklus. Untuk pelaksanaan sesungguhnya jumlah siklus sangat bergantung pada permasalahan yang perlu dipecahkan.

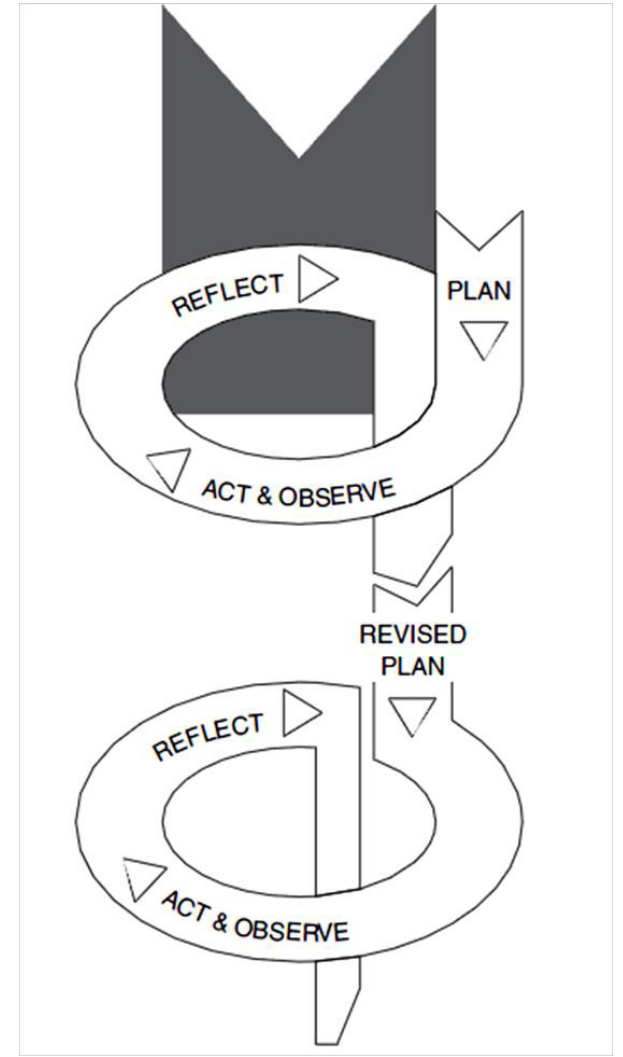

\section{Gambar 1. Model Kemmis \& Taggart (Research, 2000)}

Rencana awal sebelum siklus pertama dimulai, peneliti menyiapkan instrumen berupa tes, media pembelajaran,validasi media, petunjuk pembelajaran, dan uji coba media (tryout). Peneliti membuat instrumen untuk pre-test dan post-test. Pre-test bertujuan untuk mendapatkan data prestasi belajar sebelum diadakan tindakan post-test untuk mengetahui peningkatan prestasi belajar setelah tindakan. Post-test diberikan untuk setiap akhir siklus. Peneliti membuat media pembelajaran dengan program microsoft power point dan flash. Langkahlangkah pembuatan meliputi: (1) Rencana program; (2) Naskah program; (3) Penulisan teks; (4) Animasi; (5) perecam (background) dan 
narasi; (6) Penggabungan teks, musik pengiring (background) animasi, narasi; dan (7) Penyimpanan dalam bentuk CD. Rencana program disusun berbentuk rencana pembelajaran. Isi rencana program meliputi identitas, pokok bahasan, tujuan pembelajaran, sumber pelajaran, media, metode, dan penilaian. Identitas memuat satuan pendidikan, mata pelajaran, kelas/semester, dan tahun pelajaran. Pokok bahasan mengenai bangun ruang tiga dimensi. Tujuan pembelajaran adalah melalui media komputer siswa dapat memiliki pemahaman tentang bangun ruang. Proses pembelajaran berisi kegiatan awal, inti, dan akhir. Kegiatan awal berupa apersepsi maksudnya untuk menghubungkan pengalaman siswa dengan materi pelajaran.

Kegiatan ini berisi penerapan belajar berbantuan media komputer. Kegiatan akhir berupa pemberian umpan balik, penguatan dan motivasi belajar. Sumber pelajaran memuat buku acuan yang digunakan dalam pembelajaran. Metode yang digunakan berupa diskusi, pemberian tugas, dan demontrasi. Penilaian dilakukan secara tertulis. Naskah program merupakan teks yang akan dituangkan dalam media pembelajaran program Microsoft Power Point, Flash. Teks yang tercantum dalam naskah program isinya sesuai dengan program sesuai dengan tujuan pembelajaran. Format naskah program terdiri dari identitas, nomor slide, teks dan judul lagu. Identitas program berisi satuan pendidikan, mata pelajaran, kelas dan/semester, dan tahun pelajaran. Kolom teks berisi tulisan yang akan dimuat (dituangkan) dalam media. Penulisan teks pada program Microsoft Power Point, tulisan minimal menggunakan ukuran huruf (font size) 18. Bentuk tulisan singkat, padat, dan jelas. Jenis huruf (font) disesuaikan dengan background agar terbaca siswa.

\section{HASIL DAN PEMBAHASAN}

Peneliti membuat Lembar Kerja Siswa (LKS) untuk mengukur prestasi belajar. LKS terdiri dari 32 soal pilihan ganda dan 3 uraian, soal tersebut digunakan untuk mengukur pencapaian tujuan pembelajaran. LKS meliputi identitas dan soal soal. Identitas memuat pokok bahasan, kelas/semester. Siswa mengerjakan soal secara individu. Perhitungan nilai dilakukan dengan menggunakan rumus:

$$
\frac{\text { skor pilihan ganda }+ \text { skor uraian }}{\text { sepuluh }}
$$

Pelaksanaan belajar secara individu jadi siswa mempunyai tanggungjawab secara indivi$\mathrm{du}$ agar meyakinkan siswa bisa menyelesaikan soal sendiri, siswa dapat diketahui kemampuannya secara individu. Sebelum pelaksanaan tindakan siklus pertama, siswa mengerjakan pre-test. Maksud diadakan pre-test untuk mengetahui prestasi belajar siswa sebelum diberikan tindakan. Hasil penilaian belajar pretest dan post test pada 3 siklus yang dilakukan ditunjukkan pada Tabel 1.

\section{Tabel 1. Data Hasil Belajar Siswa}

\begin{tabular}{ccccc}
\hline $\begin{array}{c}\text { Sumber } \\
\text { Statistik }\end{array}$ & Pretest & Siklus & Siklus & Siklus \\
& & 1 & 2 & 3 \\
\hline N & 32 & 32 & 32 & 32 \\
X & 29,06 & 49,68 & 55,93 & 66,87 \\
Min & 20 & 40 & 45 & 55 \\
Max & 45 & 70 & 75 & 85 \\
\hline
\end{tabular}

Keterangan: $N$ : jumlah, $X$ : rerata, Min: minimum; Max: maksimum

Dilihat dari Tabel 1, pada tahap pre-test, siklus pertama dan siklus kedua belum mencapai nilai KKM sebesar 60. Kriteria keberhasilan tindakan diukur dari pencapaian nilai rerata $\geq$ nilai KKM (60). Meskipun demikian, pada tahap-tahap tersebut terjadi peningkatan rerata dari tahap sebelumnya. Pada siklus ketiga diperoleh nilai rerata sebesar 66,87 . Nilai tersebut lebih besar dari nilai rerata pada siklus kedua dan sudah melebihi KKM. Dikarenakan pada siklus ketiga nilai sudah mencapai kriteria keberhasilan maka siklus PTK berakhir pada siklus ketiga. 
Secara umum rerata pada tiap siklus ditunjukkan pada Gambar 2 berikut ini.

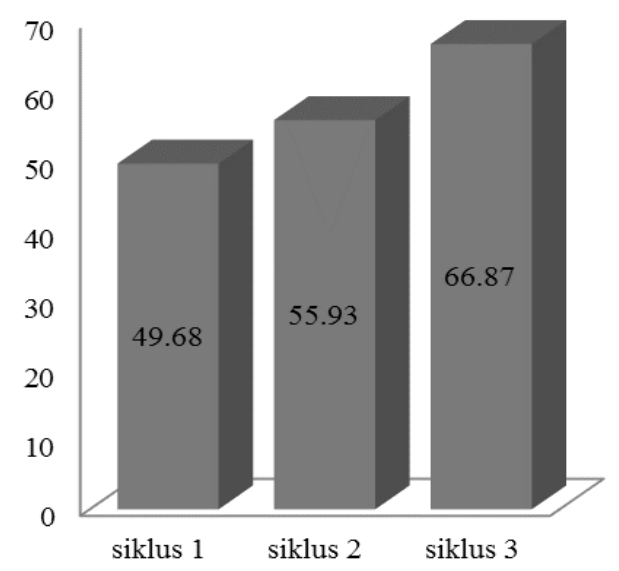

\section{Gambar 2. Peningkatan Nilai Rerata Tiap Siklus}

Gambar 2 menunjukan bahwa terjadi peningkatan nilai rerata pada tiap siklus dan pada siklus 3 diperoleh rerata yang melebihi nilai KKM. Dengan hasil tersebut maka siklus dapat dihentikan. Peningkatan rerata di Siklus 1 sebesar 20,62. Hal tersebut menunjukkan bahwa penggunaan media komputer secara signifikan mampu meningkatkan hasil belajar walaupun nilai belum memenuhi kriteria keberhasilan. Pada siklus-siklus berikutnya terjadi peningkatan dari siklus sebelumnya. Meskipun nilai peningkatan tidak sebesar peningkatan pada siklus pertama tetapi hal tersebut tetap menunjukkan bahwa tindakan yang diambil tepat untuk meningkatkan rerata hasil belajar.

Tindakan siklus pertama dilakukan tidak seluruhnya sesuai dengan rencana kegiatan yang telah disusun. Proses pembelajaran dilakukan dalam 3 kegiatan, yaitu awal, inti serta akhir. Kegiatan awal berupa apersepsi guru mengingatkan kepada siswa tentang benda benda ruang seperti Kubus, Balok, Prisma dan Limas. Guru mengingatkan pentingnya bangun ruang tersebut dalam kehidupan sehari hari. Secara khusus tujuan pembelajaran adalah siswa dapat menunjukkan sisi, rusuk, titik sudut, diagonal sisi, diagonal ruang dan bidang diagonal pada kubus, balok, prisma, dan limas. Serta dapat menghitung luas dan volume bangun ruang tersebut. Diharapkan dengan adanya apersepsi siswa mempunyai kesiapan fisik maupun mental untuk belajar. Setelah siswa menempatkan diri pada posisi masingmasing guru memberikan pengarahan tentang pembelajaran yang akan dilaksanakan. Pembelajaran dilakukan secara individu. Setiap individu disediakan satu unit komputer. Guru membagikan CD serta petunjuk pembelajaran.

Kegiatan inti berupa belajar bersama dengan menggunakan media komputer. Pembelajaran diawali dengan mempelajari pokok bahasan I yaitu tentang dimensi tiga topik yang dibahas tentang menggambar bangun ruang. Materi ini termuat dalam Microsoft Powerpoint dan media flash. Hasil pekerjaan dinilai sendiri oleh siswa dengan rumus setiap jawaban soal pilihan ganda yang benar diberi skor 2,5 kemudian 3 soal essay diberi skor 20 maka penilaian dihitung dengan rumus:

\section{Skor pilihan ganda + skor uraian 10}

Hasil pelaksanaan tindakan siklus pertama masih terdapat berbagai kekurangan. Materi pembelajaran matematika khususnya bangun ruang belum sepenuhnya dipahami oleh siswa karena kesulitan pemanfaatan media. Hal ini disebabkan oleh kemampuan penguasaan siswa terhadap pengoperasian komputer masih kurang, sedang sebagian besar siswa belum memahami sehingga ini merupakan hambatan. Selain itu siswa harus menyelesaikan sendiri dengan teman yang sudah dapat mengoperasikan komputer maka proses pembelajaran belum kondusif. Siswa merasa canggung dalam berdiskusi tentang materi pelajaran. Situasi belajar terasa agak kaku (pasif) karena siswa belum terbiasa diskusi tentang matematika, khususnya bangun ruang. Pada pembelajaran matematika berbantuan komputer ini para siswa melakukan diskusi dengan kelompok yang ditentukan oleh guru. Siswa masih pasif dalam mengikuti kegiatan pembelajaran. Siswa hanya berperan sebagai 
penonton dan pengamat, tidak terlibat dalam proses belajar. Sebagian siswa tidak terlibat dalam diskusi tentang materi pelajaran maupun pengerjaan LKS. Pada proses pembelajaran, siswa mengerjakan LKS untuk mengukur tingkat pencapaian prestasi belajar matematika. Peneliti ingin mengetahui peningkatan prestasi belajar setelah diberikan tindakan. Sebagian besar siswa masih kesulitan menyelesaikan soal yang ada di LKS.

Peneliti melakukan refleksi dan mengingat kembali proses penelitian tindakan yang telah dilakukan. Melalui diskusi dengan responden maupun kolaborator serta pengamatan dari proses perencanaan sampai hingga hasil tindakan peneliti melakukan revisi/penyempurnaan pada siklus kedua. Anggota kelompok belajar masih saling menyesuaikan diri karena siswa belum terbiasa bekerjasama dengan teman dalam kelompoknya. Hal ini disebabkan pembentukan kelompok berdasarkan atas tingkat kemampuan bukan atas kesukaan antar teman. Siswa sukar mengingat materi pelajaran matematika pokok bahasan dimensi tiga khususnya bangun ruang tentang kubus, balok, prisma, dan limas.

Siswa masih asing dengan media komputer sehingga menjadi kendala tersendiri dalam menyelesaikan soal. Para siswa masih terfokus pada bagaimana menggunakan media komputer yang belum dikuasai sementara informasi/ konsep yang terkandung didalamnya terabaikan. Sikap optimis terhadap media komputer dalam pembelajaran matematika merupakan modal utama pengembangan program proses pembelajaran selanjutnya. Ketika kelompok pembelajaran melakukan proses diskusi terjadi peserta hanya ikut ikutan saja. Siswa pasif, sebagai penonton pada saat temannya melakukan diskusi tentang materi pelajaran. Proses pembelajaran berbantuan komputer ini masih didominasi oleh sebagian kecil siswa tertentu. Pemanfaatan media belum merata kesempatan dikuasai oleh sebagian siswa saja. Teman lain tidak diberi kesempatan selalu dikuasai oleh beberapa anggota saja. Siswa lain tidak diberi kesempatan untuk mencoba pengoperasian komputer, dengan alasan takut tertinggal dengan kelompok yang lain. Hasil pengerjaan LKS dengan nilai baik bukan disebabkan oleh mahirnya dalam memanfaatkan komputer tetapi mungkin pengaruh buku-buku yang dibaca dan rajin mengerjakan soal soal latihan dan soal soal yang menantang, karena dalam menyelesaikan soal matematika latihan mengerjakan soal akan meningkatkan prestasi siswa.

Pelaksanaan tindakan pada siklus kedua, pelaksanaan ini mengacu pada refleksi siklus pertama. Penyusunan rencana dilakukan dengan mengadakan perbaikan, penyempurnaan. Peneliti membuat LKS beserta kunci jawaban. Soal soal pada LKS siklus kedua jumlah maupun bentuknya sama dengan siklus pertama. Perbedaan terletak pada variasi soal dan nomor soal. Perbedaan penyusunan dimaksudkan agar siswa tidak jenuh pembuatan LKS mengacu pada tujuan pembelajaran khusus setiap tujuan akan terukur pada soal. Guru memberikan informasi mengenai kegiatan yang harus dilakukan siswa, peneliti bersikap antisipatif agar penelitian berlangsung tertib dan sesuai dengan rencana/ tujuan. Pelaksanaan tindakan siklus kedua berjalan lebih lancar karena siswa semakin terbiasa dengan media komputer dan juga dengan kehadiran kolaborator maka proses pembelajaran menjadi semakin kondusif. Pengerjaan soal soal lebih antusias lebih cepat dari siklus sebelumnya. Kegiatan akhir, guru memberikan konfirmasi dan informasi tentang hasil belajar. Pujian serta penguatan diberikan kepada kelompok belajar dengan prestasi memuaskan. Dorongan dan penguatan diberikan kepada mereka yang belum dapat nilai bagus agar tetap belajar dan tidak putus asa dan mengejar ketinggalan, dengan memperbaiki kekurangan. Kegiatan belajar bersama lebih efektif daripada siklus pertama diantara anggota kelompok saling membelajarkan. Dalam pembelajaran berbantuan komputer tidak didominasi oleh satu orang tetapi semua siswa mengoperasikan media komputer. Pembelajaran berlangsung lancar. Siswa termotivasi untuk belajar giat. Indikatornya tampak pada keatifan dalam diskusi, dan peningkatan prestasi belajar. 
Refleksi dilakukan dengan berdiskusi antara peserta, kolaborator, maupun peneliti bahan refleksi mulai dari perencanaan hingga hasil tindakan siklus kedua. Peneliti melakukan pengamatan terhadap proses pembelajaran yang telah dilakukan. Suasana belajar aktif dikarenakan siswa mengetahui apa yang harus dilakukan. Kerja sama kelompok berlangsung secara kompak sesuai tugas masing-masing anggota dalam menyelesaikan tugas. Tidak ada dominasi antar anggota ketika melaksanakan diskusi. Siswa dapat menghargai pendapat temannya, demokratis, bersedia menerima saran maupun kritik demi suksesnya kelompok. Tugas mampu diselesaikan bersama dalam waktu lebih awal dari pada siklus pertama. Setiap anggota berusaha memberikan andil dalam kemajuan kelompok. Para siswa tidak hanya sebagai penonton tetapi berusaha mencoba untuk memberikan masukan. Suasana diskusi tampak aktif serta saling memberi dan menerima informasi tentang materi pelajaran.

Terjadi peningkatan prestasi belajar, tetapi masih terdapat materi yang belum dikuasai oleh siswa. Topik tentang kedudukan antara titik, dan bidang dalam ruang, antara lain: (1) kedudukan titik terhadap garis; (2) kedudukan titik terhadap bidang; (3) kedudukan garis terhadap bidang; (4) kedudukan garis terhadap garis lain; dan (5) perpotongan tiga bidang. Meskipun materi ini sebetulnya juga sudah dipelajari di jenjang pendidikan sebelumnya, materi ini tetap menjadi materi yang rumit, maka dalam penyusunan rencana siklus ketiga materi tentang kedudukan antara titik, garis, dan bidang dalam ruang perlu diulang agar siswa dapat mengatasi kesulitan yang dialami dalam materi menggambar bangun ruang. Caranya antara lain dengan mencantumkan berbagai variasi materi pembelajaran dalam LKS. Motivasi dan minat siswa dalam belajar meningkat, berdasarkan wawancara dan pengamatan, suasana belajar siswa menyenangkan. Dalam membahas materi pelajaran suasana tampak akrab. Siswa dapat menyesuaikan diri antar sesama teman. Siswa sudah dapat memanfaatkan media komputer dengan mudah. Mereka semakin terbiasa belajar dengan menggunakan materi dari CD. Kemudahan dalam memanfaatkan media memberikan andil dalam prestasi belajar Siswa mudah mempelajari materi pelajaran yang terdapat dalam $\mathrm{CD}$.

Hasil refleksi siklus kedua, dijadikan bahan pertimbangan prencanaan diawali dengan penyusunan LKS serta kunci jawaban. Materi pelajaran yang dianggap sukar bagi siswa akan dimasukkan soal secara bervariasi. Proses pembelajaran dilakukan dalam tiga proses kegiatan yaitu apersepsi/motivasi, inti pembelajaran, akhir/penutup. Kegiatan awal berisi apersepsi serta persiapan apersepsi sebagai pintu masuk menghubungkan pengalaman dengan materi pelajaran. Pada siklus 3 ini tidak lagi menanyakan tentang kedudukan antara titik, garis, dan bidang dalam ruang. Hal ini dimaksudkan untuk menghubungkan pengalaman siswa dengan materi pelajaran. Selain itu agar siswa mudah memahami bahan yang dianggapnya masih sulit. Guru menyajikan materi pembelajaran dengan sisi aplikatif, dimana memberikan gambaran implementasi pekerjaan yang memerlukan materi bangun ruang dengan narasi yang mudah dimengerti, seperti berikut ini.

"Arsitek suatu profesi yang sudah banyak dikenal dimasyarakat. Mungkin kalian juga bercita-cita menjadi seorang arsitek yang dapat merancang rumah, rumah sakit, pasar, bahkan gedung-gedung bertingkat. Gambar pokok yang harus dibuat seorang arsitek dalam merancang sebuah bangunan adalah gambar perspektif dan gambar tampak. Gambar tampak adalah gambar bangunan yang akan dibangun dilihat dari depan, samping, belakang dan atas. Dalam subbab ini kalian berlatih menjadi arsitek dengan melukis balok dan kubus dilihat semua sisi yang mungkin. Silahkan belajar semoga menjadi arsitek yang hebat."

Guru mengaitkan antara materi yang akan dipelajari dengan pengetahuan yang dimiliki siswa sebelumnya dan aplikasi materi. Persiapan yang dilakukan berupa penjelasan tentang langkah kegiatan, pembagian $\mathrm{CD}$ dan 
petunjuk pembelajaran. Adapun kegiatan siswa yaitu belajar bersama dengan memanfaatkan $\mathrm{CD}$ pembelajaran, mengerjakan soal secara interaktif, mengerjakan LKS dan menjawab kuis. Kegiatan akhir proses pembelajaran adalah pemberian umpan balik penguatan, motivasi belajar serta kuis. Peneliti memberikan informasi tentang tentang kemajuan belajar. Informasi berupa nilai LKS untuk setiap individu, dengan demikian siswa mengetahui prestasi, peringkat serta kekurangan yang dialami. Penguatan berupa penghargaan/pujian bagi siswa yang telah meraih prestasi baik motivasi kepada siswa agar tetap belajar giat tidak putus asa. Dorongan belajar secara khusus dipergunakan bagi kelompok berprestasi kurang agar berusaha meingkatkan belajarnya.

Pelaksanaan tindakan siklus ketiga berupa persiapan apersepsi persiapan yang dilakukan adalah meminta siswa untuk menempatkan diri di depan komputer masingmasing. Peneliti membagikan CD beserta petunjuk pembelajaran. Penjelasan lisan mengenai langkah kegiatan secara umum tetap disampaikan agar pembelajaran berjalan lancar. Peneliti memberikan pengarahan kepada siswa. Permasalahan yang dihadapi hendaknya senantiasa dipecahkan bersama melalui diskusi kelompok. Sebaiknya tidak bergantung sepenuhnya kepada guru/peneliti, siswa harus membina kerjasama berkelompok .

Pelaksanaan siklus ketiga berjalan dengan lancar, situasi pembelajaran lebih kondusif dan menarik. Siswa tidak merasa canggung maupun takut salah dalam pengoperasian komputer. Proses pembelajaran berbantuan komputer pada mata pelajaran matematika kelas X.OC berjalan dengan lancar. Kegiatan belajar berlangsung dalam situasi kondusif, dan menarik perhatian. Siswa belajar terbiasa dengan langkah-langkah kegiatan dan prosedur tindakan. Siswa memahami masalah yang harus dipecahkan. Siswa mengerjakan soal kemudian hasilnya dikumpulkan kepada guru/ peneliti kemudian dikoreksi dan hasilnya disampaikan kembali kepada siswa. Soal soal yang dianggap sulit bagi para siswa diadakan pembahasan agar siswa mengetahui kesulitan yang dihadapi kemudian dapat menyelesaikan secara mandiri. Produksi CD pembelajaran dengan menerapkan narasi atau rekaman suara mampu menambah kemenarikan suasana belajar. Narasi dapat mengurangi rendahnya tingkat keterbacaan tulisan. Adanya narasi pemahaman materi pelajaran matematika khususnya bangun ruang yang semula sulit menjadi lebih mudah dipahami.

Penyantuman soal latihan interaktif membuat siswa lebih senang menjawab pertanyaan karena jawabannya segera mendapat konfirmasi, apakah salah atau benar. Siswa merasa puas karena hasil usahanya langsung mendapat timbal balik. Kelemahannya setelah mendapatkan jawaban yang benar harusnya melanjutkan soal berikutnya tetapi tetap mencoba soal yang lain. Terjadi peningkatan rata rata prestasi belajar pada penerapan strategi belajar berbasis komputer. Pada pengerjaan LKS materi tentang kedudukan titik, garis dan bidang pada bangun ruang serta dapat menggambar bangun ruang telah dikuasai oleh sebagian besar para siswa. Peringkat belajar para siswa terjadi perubahan. Perbedaan nilai rata-rata tidak terpaut jauh antara siswa yang satu dengan siswa yang lain. Pemahaman materi pokok bahasan pertama dan kedua mengalamai peningkatan.

\section{SIMPULAN}

Penelitian Tindakan Kelas ini menunjukkan bahwa media berbantuan komputer dapat digunakan untuk meningkatkan kemampuan pemecahan masalah dalam pembelajaran matematika pada siswa SMK Negeri 1 Ngawen. Penelitian dilakukan sebanyak tiga siklus, dimana pada siklus ketiga rerata telah mencapai nilai yang melebihi KKM. Media berbantuan komputer yang dimaksud adalah berupa CD pembelajaran interaktif untuk setiap kelompok siswa yang berisi materi pembelajaran, sebagai bahan belajar mandiri dan juga bahan pembelajaran di kelas. Tahapan pembelajaran yang dilakukan dalam penelitian meliputi: (1) 
kegiatan awal berupa: (a) apersepsi sebagai pintu masuk untuk menghubungkan pengalaman dengan materi pelajaran, dimana guru mengaitkan antara materi yang akan dipelajari dengan pengetahuan yang dimiliki siswa sebelumnya dan aplikasi materi; dan (b) persiapan yang dilakukan berupa penjelasan tentang langkah kegiatan, pembagian CD dan petunjuk pembelajaran; (2) kegiatan inti berupa penggunaan media komputer yaitu siswa belajar bersama dengan memanfaatkan $\mathrm{CD}$ pembelajaran, mengerjakan soal secara interaktif (latihan soal-soal dikerjakan secara kelompok dengan bimbingan guru agar dapat bekerjasama mendiskusikan kesulitan yang ditemukan dan saling membelajarkan antar siswa), mengerjakan LKS dan menjawab kuis (secara individu untuk meningkatkan kemampuan memecahkan masalah); dan (3) kegiatan akhir proses pembelajaran berupa pemberian umpan balik penguatan, motivasi belajar, dan pemberian informasi tentang tentang kemajuan belajar (nilai LKS untuk setiap individu).

\section{DAFTAR RUJUKAN}

Ansyar, M. 2003.Kontribusi Telaah Matematika Terapan bagi Terlaksananya Kurikulum Matematika Berbasis Kompetensi.Makalah disajikan dalam Seminar Nasional MatematikaXI di Universitas Negeri Yogyakarta

Azhar Arsyad. 2007. Media Pembelajaran. Jakarta: PT Raja Grafindo Persada.

Hujair AH. Sanaky (2009) Media Pembelajaran. Yogyakarta: Safiria Insania Press

Kemmis and Mc Taggart. 1990. The Action Research. Planner University
Muhammad Faiq. 2009. Penelitian Tindakan Kelas - Upaya peningkatan Mutu Pendidikan. Diambil dari http://pe nelitiantindakankelas.blogspot.co.id/20 09/02/penelitian-tindakan-kelasupaya.html

Purnama Kadir. 2013. Kendala pemanfaatan TIK dalam dunia pendidikan.Makalah dengan dosen pembina Azizah. Diambil dari http://purnamakadir.blog spot.co.id/2013/03/kendalapemanfaatn-tik-dalam-dunia.html

Suhas Caryono \& Suhartono. 2012. Analisis deskriptif faktor penyebab kesulitan belajar mata pelajaran matematika di SMA Negeri 8 Purworejo tahun pelajaran 2012/2013. Prosiding Seminar Nasional Matematika dan Pendidikan Matematika 10 November 2012, Jurdik Matematika FMIPA UNY. Hal: 819-826

Research methodology. 2000. Kemmis and McTaggart's Action Research Spiral. Diambil dari http://research-methodology.net/research-methods/action-research/

Rusefendi, ET. 1992. Dasar-Dasar Matematika Modern untuk Guru. Bandung: Tarsito

Suwarsih, Madya. 2006. Teori dan Praktek Penelitian Tindakan (Action Research) Bandung: Alfabeta

Wagiran. 2015. Panduan Praktis Menyusun Proposal dan Laporan PTK. Disampaikan pada PPM PPs UNY di SMKN 1 Ngawen 2015. 